\title{
DNA Barcoding unveils cryptic lineages of Hoplias malabaricus from Northeastern Brazil
}

\author{
W. M. M. Pires ${ }^{a, b}$ (D), M. C. Barros ${ }^{b, c}$ (D) and E. C. Fraga ${ }^{b, c *}$ (D) \\ aUniversidade Estadual do Maranhão - UEMA, Programa de Pós- Graduação em Biodiversidade Ambiente e Saúde, \\ Laboratório de Genética e Biologia Molecular, Caxias, MA, Brasil

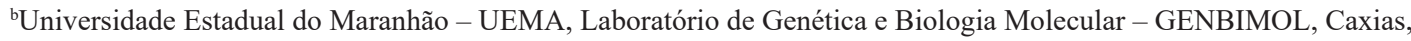 \\ MA, Brasil \\ 'Universidade Estadual do Maranhão - UEMA, Departamento de Química e Biologia, Caxias, MA, Brasil \\ *e-mail: elmaryfraga@yahoo.com.br
}

Received: November 29, 2019 - Accepted: April 29, 2020 - Distributed: November 30, 2021

(With 3 figures)

\begin{abstract}
The trahira or wolf fish - Hoplias malabaricus- is a valid species, although recent cytogenetic and molecular studies have indicated the existence of a species complex. In this context, the present study analyzed the mitochondrial COI marker to determine the levels of genetic diversity of specimens from the Brazilian state of Maranhão, and verify the occurrence of distinct lineages within the study area. Samples were collected from the basins of the Turiaçu, Pindaré, Mearim, Itapecuru, and Parnaíba rivers. A 630-bp fragment was obtained from 211 specimens, with 484 conserved and 108 variable sites, and 60 haplotypes $(\mathrm{Hd}=0,947 ; \pi=0,033)$. The phylogenetic analyses indicated the existence of three distinct lineages of $H$. malabaricus from Maranhão. Genetic distances of $1.5-8.2 \%$ were found between all the populations analyzed, while the variation between haplogroups ranged from $2.1 \%$ to $7.7 \%$. The AMOVA indicated that most of the molecular variation was found among groups, with high FST values. The high levels of genetic variability found in the present study are supported by the available cytogenetic data. These findings reinforce the need for the development of effective programs of conservation and management independently for each river basin, in order to preserve the genetic variability found in this taxon.
\end{abstract}

Keywords: cytotype, COI, species complex, cryptic speciation, trahira.

\section{DNA Barcoding revela linhagens crípticas de Hoplias malabaricus no nordeste do Brasil}

\section{Resumo}

A traíra - Hoplias malabaricus- é uma espécie válida, embora recentes estudos citogenéticos e moleculares tenham indicado a existência de um complexo de espécies. Neste contexto, o presente estudo analisou o marcador mitocondrial COI para determinar os níveis de diversidade genética dos espécimes do estado do Maranhão e verificar a ocorrência de linhagens distintas dentro da área de estudo. As amostras foram coletadas nas bacias dos rios Turiaçu, Pindaré, Mearim, Itapecuru e Parnaíba. As análises filogenéticas indicaram a existência de três linhagens distintas nas populações do Maranhão. Obteve-se um fragmento de 630 pb de 211 espécimes, com 484 sítios conservados, 108 variáveis e 60 haplótipos $(\mathrm{Hd}=0,947 ; \pi=0,033)$. As análises filogenéticas indicaram a ocorrência de três linhagens distintas de H. malabaricus do Maranhão. Distâncias genéticas de 1.5 a $8.2 \%$ foram encontradas entre todas as populações analisadas, enquanto a variação entre os haplogrupos variou de $2.1 \%$ a $7.7 \%$. A AMOVA indicou que a maior variação molecular foi entre os grupos, com altos valores de FST. Os altos níveis de variabilidade genética encontrados no presente estudo são suportados pelos dados citogenéticos disponíveis. Essas descobertas reforçam a necessidade de desenvolver programas de conservação e manejo independentemente para cada bacia hidrográfica, a fim de preservar a variabilidade genética encontrada neste táxon.

Palavras-chave: citótipos, COI, complexo de espécies, especiação críptica, traíra.

\section{Introduction}

The family Erythrinidae encompasses a small group of Neotropical characiforms, known as trahiras or wolf fish. It comprises of about 15 valid species distributed in the genera Erythrinus Scopoli, 1777, Hoplerythrinus Gill, 
1985, and Hoplias Gill, 1903 (Bifi, 2013). The family is endemic to South and Central America. Despite being a relatively small group, the precise identification of the species remains problematic (Oyakawa and Mattox, 2009).

Hoplias malabaricus has an elongated, cylindrical body, covered with cycloid scales, and an enlarged head, wide mouth, and rounded caudal fin, with black dots. The coloration of this fish is golden brown, with some dark patches, although this may vary with age. The teeth are robust, conical, and varying in size. The palate has two rows of conical denticles in a $\mathrm{V}$ - shaped configuration (Bertollo et al., 2000). Wolf fish are carnivorous predators of aquatic insects, shrimp, and small fish, which they capture by sit-and-wait foraging. Hoplias. malabaricus is well adapted to lentic environments, although it may also be found in rivers, of all sizes, where it prefers areas with vegetation, in which it can hide and wait for prey (Prado et al., 2006). In addition to its ecological importance, this species is an important resource for both artisanal and commercial fisheries, given its abundance in some areas, where it is an important source of food for local fishing communities (Barros et al., 2007).

Hoplias malabaricus has been the focus of cytogenetic studies since the 1970s (Bertollo et al., 2000; Pazza and Júlio Júnior, 2003; Vicari et al., 2005; Jacobina et al., 2009, 2011; Blanco et al., 2010; Marques et al., 2013; Utsunomia et al., 2014; Grassi et al., 2017). In addition to these studies, more recent - molecular research (Santos et al., 2009; Pereira et al., 2013; Marques et al., 2013; Peres et al., 2002; Rosso et al., 2012, 2018; Abreu-Souza, 2014; Jacobina et al., 2018) has provided increasing evidence of the existence of a species complex within this taxon, with seven recognized cytotypes and a high degree of genetic diversity, which is consistent with reproductive isolation.

Some of the H. malabaricus cytotypes (for example $2 \mathrm{n}=42 \mathrm{~A}, 2 \mathrm{n}=40 \mathrm{C}$ and $2 \mathrm{n}=40 \mathrm{~F}$ ) are widely distributed in South America, while others are endemic to specific Brazilian river basins (Rosa et al., 2014). As the number of study areas has increased, the known cytogenetic diversity of H. malabaricus has also expanded progressively, to much higher levels than previously thought, with variation being found even within populations defined by a single cytotype (Vicari et al., 2005; Blanco et al., 2010). These differences are apparent at molecular, cytogenetic, and even morphometric levels.

In taxonomy, morphological data has always been the primary criteria for the identification of species. The different approaches to the species concept have received increasing attention in recent years, and a number of different methods have been proposed for the delimitation of species status (Wiens and Penkrot, 2002). More recently, approaches based on DNA sequencing have become increasingly popular, making this method especially effective as a complementary tool to morphology for the identification of taxa (Ward et al., 2005, 2009; Hebert et al., 2003). Hebert et al. (2003) proposed the use of a sequence of approximately $650 \mathrm{bps}$ of the mitochondrial gene Cytochrome Oxidase Subunit I
$(C O I)$ for the identification of animal taxa at the species level, even in the case of cryptic species.

The available data indicate that $H$. malabaricus is taxonomically confusing and genetically diverse and is in fact a complex of cryptic species. Given this, the present study applied the $\mathrm{COI}$ marker to unveil the genetic diversity of $\mathrm{H}$. malabaricus specimens from the Brazilian state of Maranhão, as well as determine whether the possible local cytotype(s) are characterized by high levels of genetic diversity. The understanding of the genetic variability of the populations of this species found in the rivers of Maranhão will be fundamental to the future development of effective programs of conservation and management. The results of the study indicate the existence of several different genetic lineages in the Maranhão populations, which may even be consistent with the presence of more than one species in a given river basin.

\section{Material and Methods}

\subsection{Sampling}

The study (Table 1) included a total of 144 specimens of $H$. malabaricus collected from the basins of the Itapecuru, Pindaré, Mearim, Parnaíba, and Turiaçu rivers between 2010 and 2016 (Figure 1). The specimens were collected using a variety of fishing techniques, including dragnets, gillnets (of varying mesh sizes), and cast nets, and weirs. All the specimens were euthanized by immersion in freezing water (Ashley, 2007) and deposited in the scientific collection of the Laboratory of Genetics and Molecular Biology of the Caxias campus of Maranhão State University in Caxias, northern Brazil.

The specimens were identified as H. malabaricus, based on Oyakawa and Mattox (2009), with the identification being confirmed subsequently by fish taxonomist. Five voucher specimens were deposited in the Museum of Zoology of Londrina State University (MZUEL) in Londrina, Paraná, Brazil. The collection of specimens was authorized by ICMBioMMA, through licenses 02012.004159/2006 (Itapecuru River), 46367-1 (Pindaré River), 42.119-2 (Mearim River), and 46367-1 (Turiaçu River).

\subsection{Extraction of the DNA, PCR, and sequencing}

Total DNA was extracted from muscle tissue using a commercial Promega Wizard $\AA$ Genomic DNA Purification, according to the manufacturer's instructions. A $650-\mathrm{bp}$ sequence of the 5' region of the Cytochrome Oxidase I (COI) gene was isolated using the COIF1/COIR1 primers (Ward et al., 2005). The PCR was run in a final volume of $25 \mu \mathrm{l}$, with $1 \mu \mathrm{L}(250 \mathrm{ng} / \mathrm{mL})$ of the DNA, $0.25 \mu \mathrm{L}$ $(200 \mathrm{ng} / \mathrm{mL}$ ) of each primer (forward and reverse), $2.5 \mu \mathrm{L}$ of $10 \mathrm{x}$ buffer ( $200 \mathrm{mM}$ Tris- $\mathrm{HCl}, \mathrm{pH} 8.4$, and $500 \mathrm{mM} \mathrm{KCl}$ ), $4 \mu \mathrm{L}(1.25 \mathrm{mM})$ of DNTPs, $0.5 \mu \mathrm{L}(50 \mathrm{mM})$ of $\mathrm{MgCl}_{2}$, $0.2 \mu \mathrm{L}$ of $5 \mathrm{U} / \mathrm{mL}$ Taq DNA polymerase, and distilled water to complete the final reaction volume.

The PCR protocol was as follows: 2 minutes at $95^{\circ} \mathrm{C}$ for denaturation, followed by 35 cycles of 30 seconds at $94{ }^{\circ} \mathrm{C}, 60 \mathrm{~s}$ at $56^{\circ} \mathrm{C}$ and 60 seconds at $72{ }^{\circ} \mathrm{C}$, followed 
Table 1. Collecting localities, number of Hoplias malabaricus specimens collected.

\begin{tabular}{|c|c|c|c|}
\hline River basin & Number of specimens & Year of collection & Reference \\
\hline \multirow[t]{5}{*}{ Itapecuru } & 6 & 2006 & Present study \\
\hline & 6 & 2008 & \\
\hline & 14 & 2008 & \\
\hline & 6 & 2006 & \\
\hline & 18 & $2,008,201,220,132,010$ & \\
\hline \multirow[t]{4}{*}{ Mearim } & 7 & 2011 & Present study \\
\hline & 7 & 2014 & \\
\hline & 6 & 2014 & \\
\hline & 6 & 2015 & \\
\hline Pindaré & 27 & 2011, 2015 & Present study \\
\hline \multirow[t]{3}{*}{ Parnaíba } & 8 & 2013 & Present study \\
\hline & 7 & 2015 & \\
\hline & 8 & 2015 & \\
\hline Turiaçu & 33 & 2013,2015 & Present study \\
\hline São Francisco & 9 & - & $\begin{array}{l}\text { HQ600828-HQ600825; } \\
\text { HM906020-HM405122 }\end{array}$ \\
\hline Paraná & 8 & - & $\begin{array}{l}\text { JN988909-JN9889907; } \\
\text { KU288883-KU288786 }\end{array}$ \\
\hline River Plate & 4 & - & $\begin{array}{l}\text { JX111760, JX111761, } \\
\text { JX11762, JX11163 }\end{array}$ \\
\hline Amazon & 28 & - & JX112659-JX112693 \\
\hline Patos Mirim Lagoon & 18 & & KC250469-KC250448 \\
\hline
\end{tabular}

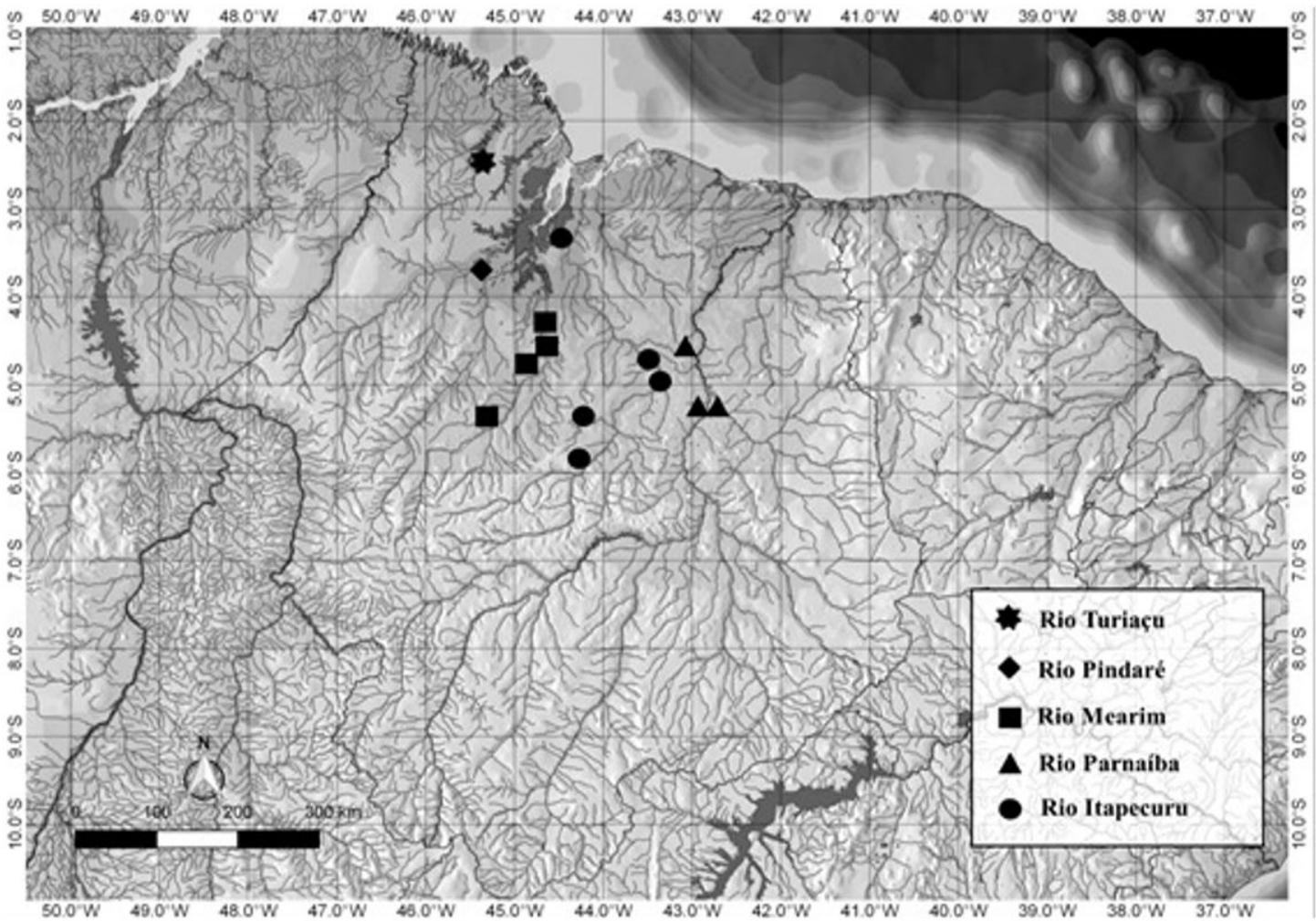

Figure 1. Location of the collecting points in each river basin. Map created using Quantum GIS 2.6. 
by a final extension of 7 minutes at $72{ }^{\circ} \mathrm{C}$. The PCR products were purified using an ExoSap-IT kit (USB Corporation), following the manufacturer's instructions. The purified products were sequenced using the Sanger et al. (1977) method, with the Big Dye Terminator v.3.1 Cycle Sequencing Ready Reaction kit (Applied Biosystems, Foster City, CA, USA). The samples were sequenced in an ABI 3500 automatic sequencer (Life Technologies). The samples were sequenced in both directions (forward and reverse).

\subsection{Data analysis}

The BoldSystems (2019; Ratnasingham and Hebert, 2007) and Blast platforms were used to verify the percentage similarity among the samples analyzed in the study. For the phylogenetic reconstruction, additional $67 \mathrm{COI}$ sequences of $H$. malabaricus were downloaded from the Genbank. These sequences were included in the analysis to determine whether the geographic distance between specimens influences their genetic divergence.

The sequences were aligned in CLUSTAL W 1.4 (Thompson et al., 1994), which was run in BIOEDIT 7.0 (Hall, 1999). The GENEIOUS program, version 4.8.5 (Biomatters), was used to obtain the consensus sequence and verify the presence of stop codons, as required for the validation of the barcoding sequence. The most adequate evolutionary model for the phylogenetic reconstruction was identified using Modelgenerator 0.85 (Keane et al., 2006). The phylogenetic tree based on Bayesian Inference was then generated in MrBayes 3.1.2. (Ronquist and Huelsenbeck, 2003), and convergence was verified in Tracer 1.5 (Rambaut and Drummond, 2009). The support for the nodes was estimated using a Shimodaira-Hasegawa-like (SH-aLRT) interpretation (Anisimova et al., 2011).

The genetic polymorphism was retrieved in DnaSP 5.10 (Librado and Rozas, 2009). Evidence of selection in the populations was derived from the $\mathrm{D}$ (Tajima, 1989) and Fs (Fu and Li, 1993) tests. The matrix of genetic distance was generated in MEGA 7 (Kumar et al., 2016), based on the Kimura 2-parameter (K2P) evolutionary model (Kimura, 1980). A haplotype network was produced in Haploviewer (Salzburger et al., 2011) to determine the degree of correlation between the drainage basins and the evolutionary lineages, and infer the evolutionary relationships among the different species.

The possible existence of differentiated populations and the significance of inter- and intra-population variability were verified using an Analysis of Molecular Variance (AMOVA). Three different levels of hierarchy were adopted in the AMOVA, one which included only the populations from Maranhão, one which included the COI sequences of $H$. malabaricus obtained from GenBank, and the third considering the haplogroups observed in the BAPS analysis. The fixation index (FST) and its significance were obtained from 1023 random permutations. The neutrality tests of AMOVA and fixation indices were obtained in the Arlequin 3.5 program (Excoffier et al., 2007).
The hierarchy population structure was also analysed using the Bayesian algorithm, run in BAPS 6.0 (Corander et al., 2008). These analyses were based on the population mixing model with individual grouping and $\mathrm{k}$ values of between 2 and 5. The log-likelihood score was used to determine the best model and provided a parameter for the definition of the most probable grouping.

\section{Results}

A 630-bp fragment of the mitochondrial COI gene was obtained for $211 \mathrm{H}$. malabaricus specimens. No evidence was found of the presence of insertions, deletions, stop codons or any other alterations of the sequence of amino acids, which validates the sequences obtained here as part of the functional region of the COI gene. The analyses of the nucleotides revealed 484 conserved sites, and 108 variable sites, of which 99 were informative for parsimony analysis. A total of 60 haplotypes $(\mathrm{Hd}=0,947$; $\pi=0,033)$ were identified. The results of the neutrality tests (Tajima's D $=-0,11437$, Fu's $F=-12,553$ ) were negative and non-significant $(\mathrm{p}>0.10)$, indicating the recent expansion of the study populations.

The identification of the specimens was confirmed through the comparison of the nucleotide sequences with those deposited in the BOLDSystems database. The BLAST searches returned a $99.50-100 \%$ similarity between the specimens from the Amazon, Paraná, Plate, and São Francisco basins, and those from the rivers of Maranhão. However, the specimens from the Patos Mirim Lagoon were 100\% similar to the sequence of Hoplias sp. vieirai found in the BOLDSystems database. Even so, these specimens were $98.67 \%$ similar to the $H$. malabaricus sequence, which is within the $2 \%$ threshold for the differentiation of species using the DNA barcode.

The phylogenetic analyses produced haplotype trees with four - well-supported clades - distributed as follows: Clade I - Paraná + Amazon basins; Clade II - Paraná River +Argentina + Patos Mirim Lagoon; Clade III - specimens from the Maranhão basins (Itapecuru + Pindaré + Parnaíba + Turiaçu + Mearim) and the Amazon River, Clade IV- São Francisco basin. A more detailed analysis of the topology revealed the existence of several different haplogroups, including five in the basins of the rivers of Maranhão, with bootstrap support ranging from 0.78 to 0.99 (Appendix S1).

The result of the analysis haplotype network indicated a clear separation between two haplogroups: - one formed by the haplotypes from the Paraná and Plate basins, together with the Patos Mirim lagoon, and the other, by those from the Paraná and Amazon basins. In addition to these two genetically distant groups, the populations from Maranhão were distributed in different lineages, with three distinct haplogroups. The first of these haplogroups includes haplotypes from the Turiaçu, Mearim, Pindaré, Itapecuru, and Parnaíba rivers, together with the Amazon. The second haplogroup encompasses one lineage from the Parnaíba basin, one from the Amazon, and the haplotypes from the São Francisco River. The third haplogroup from 
Maranhão was formed by the specimens from the Parnaíba, Itapecuru, and Pindaré basins (Figure 2).

The mean genetic distance between populations from river basins ranged from $1.5 \%$ to $8.2 \%$ when the Brazilian haplotypes are compared with those from Argentina. The distances between the specimens from Maranhão varied from $0.8 \%$ to $2.7 \%$, while the distances between these specimens and those from the Amazon basin range from $3.7 \%$ to $4.4 \%$. Mean intraspecific diversity was $0.18-4.77 \%$. All other parameters are shown in Table 2. An additional analysis was run to determine the genetic distances between the haplogroups indicated by the haplotype network, which returned distances of between $2.1 \%$ and $7.7 \%$, while those between the Maranhão lineages varied from $2.1 \%$ to $3.3 \%$ (Table 3 ).

The results of the AMOVA indicate that most of the variation was among groups, with significant $\mathrm{F}_{\mathrm{ST}}$ values. When the specimens from Maranhão were analyzed separately, most $(64.01 \%)$ of the variation was also found among populations. To confirm the existence of three distinct

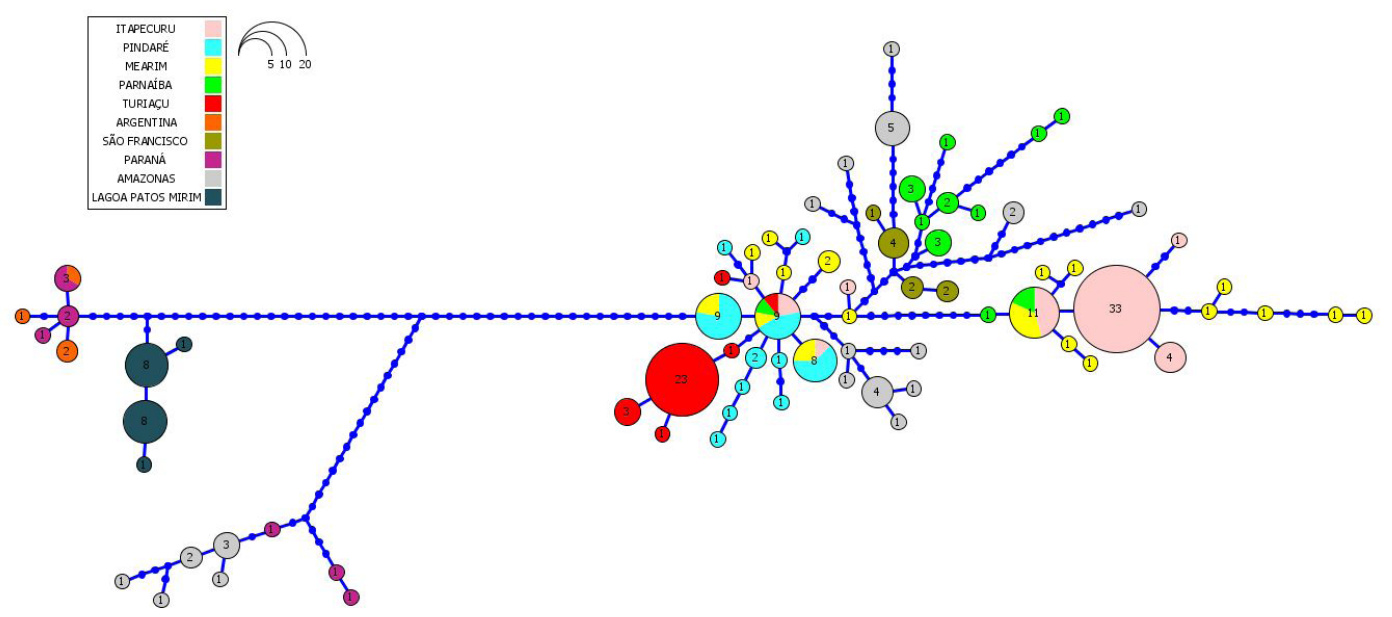

Figure 2. Haplotype network generated for the H. malabaricus populations based on the COI gene. The size of each circle is proportional to the frequency with which each haplotype was recorded.

Table 2. Mean K2P genetic distances for the COI gene in H. malabaricus, considering each population as a distinct grouping. The values in the diagonal (bold type) refer to the mean intraspecific diversity.

\begin{tabular}{lllllllllll}
\hline \multirow{2}{*}{ Population } & \multicolumn{10}{c}{ \% Nucleotide divergence } \\
\cline { 2 - 11 } & $\mathbf{1}$ & $\mathbf{2}$ & $\mathbf{3}$ & $\mathbf{4}$ & $\mathbf{5}$ & $\mathbf{6}$ & $\mathbf{7}$ & $\mathbf{8}$ & $\mathbf{9}$ & $\mathbf{1 0}$ \\
\hline 1. Itapecuru & $\mathbf{1 . 2 7}$ & & & & & & & & & \\
2. Mearim & 1.5 & $\mathbf{1 . 6 8}$ & & & & & & & & \\
3. Pindaré & 1.6 & 2.0 & $\mathbf{0 . 5 3}$ & & & & & & & \\
4. Parnaíba & 2.3 & 2.7 & 2.1 & $\mathbf{1 . 3 7}$ & & & & & & \\
5. Turiaçu & 1.7 & 2.2 & 0.8 & 2.3 & $\mathbf{0 . 4 7}$ & & & & & \\
6. São Francisco & 2.0 & 2.5 & 1.7 & 1.3 & 1.9 & $\mathbf{0 . 3 7}$ & & & & \\
7. Paraná & 7.2 & 7.5 & 6.8 & 7.0 & 7.2 & 6.9 & $\mathbf{4 . 7 7}$ & & & \\
8. River Plate & 7.8 & 8.2 & 7.5 & 7.5 & 8.0 & 7.5 & 4.0 & $\mathbf{0 . 4 7}$ & & \\
9. Amazonas & 4.0 & 4.4 & 3.5 & 4.1 & 3.7 & 3.6 & 6.7 & 8.1 & $\mathbf{4 . 4 9}$ & \\
10. Patos Mirim & 7.2 & 7.6 & 6.9 & 6.8 & 7.4 & 6.8 & 4.3 & 1.5 & 7.2 & $\mathbf{0 . 1 8}$ \\
\hline
\end{tabular}

Table 3. Mean K2P genetic distance for the COI gene in the haplogroup of H. malabaricus according to the pattern verified in the haplotype network and the BAPS analysis.

\begin{tabular}{lccccc}
\hline \multirow{2}{*}{ Haplogroup } & \multicolumn{5}{c}{ \% Nucleotide divergence } \\
\cline { 2 - 6 } & $\mathbf{1}$ & $\mathbf{2}$ & $\mathbf{3}$ & $\mathbf{4}$ & $\mathbf{5}$ \\
\hline Haplogroup 1 & & & & & \\
Haplogroup 2 & 6.8 & & & & \\
Haplogroup 3 & 7.5 & 5.9 & 2.9 & 3.3 \\
Haplogroup 4 & 7.3 & 5.7 & 2.1 & \\
Haplogroup 5 & 7.7 & 6.2 & &
\end{tabular}


lineages in the rivers of Maranhão, an additional AMOVA was run, considering the haplogroups indicated by previous analyses. In this scenario, most of the variation (55.05\%) was among populations, with an $\mathrm{F}_{\mathrm{ST}}$ value of 0,550 , with a highly significant $p$ value, of less than 0.0001 (Table 4).

The results of the BAPS program demonstrated the existence of two different lineages in the Itapecuru and Mearim basins, and three in the Parnaíba basin, although only a single lineage was found in the Pindaré and Turiaçu basins. This pattern was upheld when the GenBank specimens were included in the analysis. Three distinct lineages were found in the Amazon and Paraná basins, whereas a single lineage was found in the River Plate and Patos Mirim Lagoon (Figure 3). Both the haplotypes network and the BAPS analysis indicated the existence of three evolutionary lineages in the specimens from Maranhão, which are undergoing genetic differentiation consistent with a process of speciation. It is important to note here that the existence of these three lineages is corroborated by the minor morphological variation found in specimens from Maranhão in previous studies.

\section{Discussion}

The effectiveness of the DNA barcode for the evaluation of biodiversity and the resolution of taxonomic problems, such as species identification and discovery of cryptic diversity on fish species, cannot be over-emphazied., delimitation of species in a large number of taxa (Hebert et al., 2003; Clare et al., 2006; Ward et al., 2009). Our study demonstrates the relevance of DNA barcoding for the identification and uncovering lineage diversity of fish species from Brazil. This study contributes DNA barcode data that would be important in identification of H. malabaricus which in turn will aid the management of this economically important fish species.

Further, our study recovered several lineages of H. malabaricus from Brazil. Similar to the studies of Posada and Crandall (2001) our study revealed that gene

Table 4. Results of the AMOVA of the H. malabaricus populations analyzed in the present study.

\begin{tabular}{|c|c|c|c|c|}
\hline Type of variation & $\begin{array}{l}\text { Component of the } \\
\text { variation }\end{array}$ & $\begin{array}{c}\% \text { of } \\
\text { the total } \\
\text { variation }\end{array}$ & $F_{S T}$ & $p^{*}$ \\
\hline \multicolumn{5}{|c|}{ Six groups (Maranhão rivers, São Francisco, Amazon, Paraná, Patos Mirim and River Plate) } \\
\hline Between groups & $726,059 \mathrm{Va}$ & 49.67 & 0.750 & $<0.0001$ \\
\hline $\begin{array}{l}\text { Between populations of the } \\
\text { same group }\end{array}$ & $370,675 \mathrm{Vb}$ & 25.36 & & \\
\hline Within populations & $364,947 \mathrm{Vc}$ & 24.97 & & \\
\hline \multicolumn{5}{|c|}{ Maranhão group (Itapecuru, Pindaré, Mearim, Parnaíba, Turiaçu) } \\
\hline Between populations & $376,183 \mathrm{Va}$ & 64.01 & 0.640 & $<0.001$ \\
\hline Within populations & $211,547 \mathrm{Vb}$ & 35.99 & & \\
\hline \multicolumn{5}{|l|}{ Five haplogroups } \\
\hline Among populations & $752,810 \mathrm{Va}$ & 55,05 & 0.550 & $<0.001$ \\
\hline Within populations & $614,804 \mathrm{Vb}$ & 44.95 & & \\
\hline
\end{tabular}

*p values, calculated randomly with 1023 permutations.

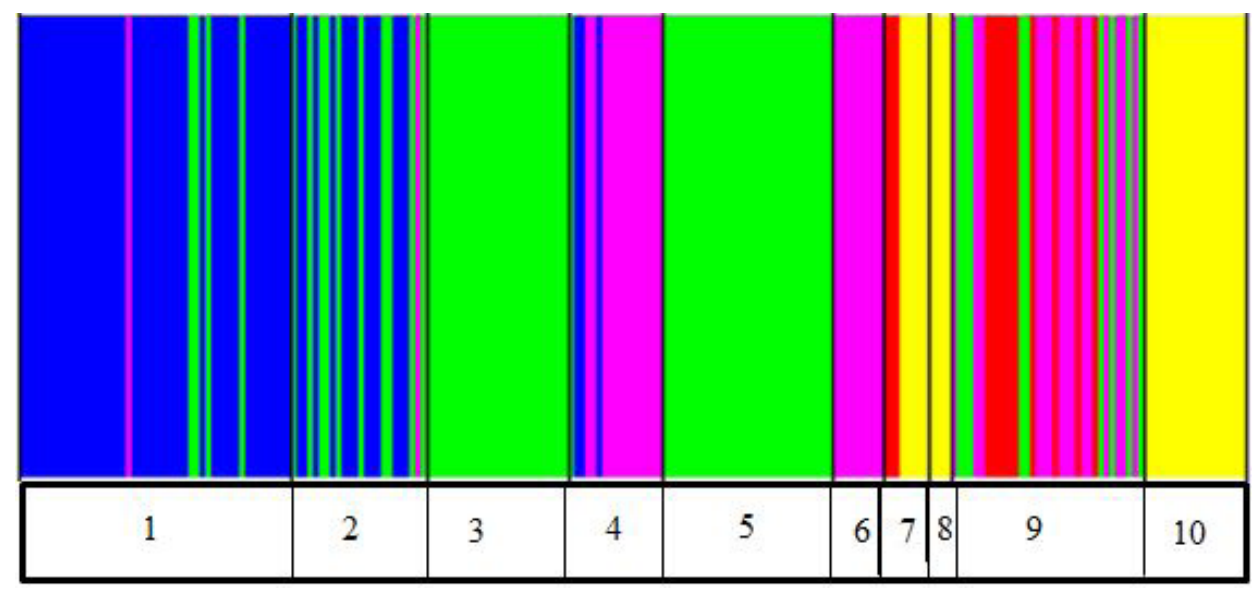

Figure 3. Bar chart generated by the analysis run in BAPS v.6, which estimates the posterior probability of the formation of the different groups. Each group is represented by a different color, and the populations are numbered as follows: (1) Itapecuru; (2) Mearim; (3) Pindaré; (4) Parnaíba; (5) Turiaçu; (6) São Francisco; (7) Paraná; (8) River Plate; (9) Amazon; and (10) Patos Mirim. 
trees may not represent the most effective approach for the identification of intraspecific groups, due to their reduced resolution, whereas haplotype networks may be the most reliable approach. This was apparent in the present study, given that the gene trees provided a confusing picture, whereas the haplotype network produced a hierarchy consistent with that of the other analytical approaches, and the same arrangement of haplogroups. This appears to reflect a relatively recent process of diversification, on an evolutionary time scale, with the incomplete separation of lineages and the formation of different haplogroups, which separate the different lineages of $H$. malabaricus found in the rivers of Maranhão.

This result was further reinforced by the BAPS analysis, which also indicated the formation of haplogroups encompassing different lineages of $H$. malabaricus from Maranhão. This indicates that, while all population of H. malabaricus included in this study have the same cytotype, their genetic divergence is consistent with the separation of the lineages in different clades.

The phylogenetic reconstruction revealed the formation of at least five different haplogroups in the populations from Maranhão. This may indicate the existence of distinct lineages in the local rivers. In an analysis of the D-Loop of the H. malabaricus populations of river basins in Maranhão (the Turiaçu, Pindaré, Mearim, Itapecuru, Parnaíba) Pires et al. (2019) found a high degree of genetic variability (haplotype diversity of 0.984 and nucleotide diversity of 0.044 ) and three principal haplogroups in the populations from Maranhão, with well-supported bootstrap values of $88-98 \%$. The mean genetic distance between groups ranged from $3.4 \%$ to $5.9 \%$, with the population from the Pindaré River being the most differentiated.

Previous studies of Hebert et al. (2003) showed that high rates of intraspecific divergence may be found in geographically isolated populations. However, the findings of the present study indicate high levels of genetic differentiation within a single river basin, resulting in the presence of distinct lineages. Similarly, Santos et al. (2009) also recorded high levels of genetic divergence in a study of the H. malabaricus populations of twelve basins in eastern Brazil (located in the proximity of the watersheds), based on both karyotyping and the analysis of sequences of the mitochondrial ATPase 6 gene. The high level of divergence found in the present study thus appears to be due to local adaptation of the species.

The ecological characteristics of the species should also be considered in any interpretation of evolutionary patterns. Sedentary species tend to be less able to overcome physical barriers or avoid environmental pressures, leading to a greater accumulation of the effects of vicariant events or ecological processes in their DNA(López-Fernández et al., 2013). This may favor an increase in the genetic diversity within the populations of the different river basins, as observed in the present study.

The results of the present study indicate that the levels of genetic divergence of the $H$. malabaricus specimens may not be restricted to the different hydrographic basins, but may be found in sympatric individuals, as observed in the populations of the Itapecuru, Mearim, Pindaré, and Parnaíba rivers, where at least two lineages were identified, indicating the possible presence of a complex of cryptic species.

The present-day diversity and distribution of freshwater fish species may be determined by a range of factors, including the geomorphological history of the river basins they inhabit (Lundberg et al., 1998; Hubert and Renno, 2006). In the case of Brazilian river systems, one of the primary processes is the variation in sea levels provoked by cycles of glaciation (Weitzman et al., 1998). In particular, the fall in sea level during peak glaciation events may favor the confluence of adjacent river basins, and the dispersal of fish populations between these basins.

In the case of the Turiaçu basin, Nores (2004) noted that, during the Miocene-Pliocene transition, approximately 5 million years ago, sea levels increased by $100 \mathrm{~m}$ over a period of 800,000 years. During this period, the Turiaçu basin would have been flooded with seawater, eliminating its populations of freshwater fish. When sea levels receded, these species eventually returned to the basin.

One other process that may account for the similarities of the fauna between basins is headwater capture, which permits the dispersal of ancestral lineages, which may then diverge allopatrically in neighboring basins. Headwater capture occurs when part or all of the basin of one river is diverted to that of a neighboring river through differential rates of erosion, tectonic upraising or landslides, resulting in vicariant events and dispersal (Albert and Reis, 2011). One of the consequences of this process is the formation of non-monophyletic subclades within the population of one river that are derived from the lineages of adjacent rivers (Lundberg et al., 1998). This may account for the sharing of haplotypes between geographically isolated rivers, as observed in the present study.

The more recent the separation of populations or species, the more likely will be the sharing of haplotypes, a phenomenon known as the incomplete separation of lineages (Takahashi et al., 2001). In this case, the period that separates the lineages may not be enough to allow for the establishment of clear genetic differences (Sites Junior and Marshall, 2004). The pattern of the distribution and sharing of haplotypes found in the present study is consistent with a scenario of this type. The recent divergence of species hampers the identification of valid taxa.

In conclusion, our study is extremely important, given that changes occurring in a species at the molecular level may not always be apparent in their morphology, reinforcing the need for the integration of genetic, cytogenetic, morphological, and ecological approaches for fish taxonomy and diversity studies. While a more thorough taxonomic review, integrating morphological, molecular (mitochondrial and nuclear) and cytogenetic data is required, the distinct lineages identified in the present study should be considered as a separate evolutionary unit. Finally, further study is required to determine the evolutionary processes governing the diversification of 
H. malabaricus in Brazil. Such study is important, for the development of effective measures for the conservation of species.

\section{Acknowledgements}

This study was supported financially by FAPEMA and CAPES. We would also like to thank José Olivan Biridelli for the taxonomic identification of the specimens, Bruno Augusto Torres Parahyba Campos (post-doc researcher at the Caxias campus of UEMA) for his assistance with the analyses, and all the local fishermen who helped collect specimens.

\section{References}

ABREU-SOUZA, C.P., 2014. Diversidade e morfométricas de Hoplias malabaricus (Bloch, 1794) em drenagens do estado do Maranhão. São Luís: Universidade Federal do Maranhão, 36 p. Dissertação de Mestrado em Biodiversidade e Conservação.

ALBERT, J.S. and REIS, R.E., 2011. Introduction to neotropical freshwaters. In: J. S. ALBERT and R. E. REIS, eds. Historical biogeography of neotropical freshwater fishes. Berkeley: University of California Press, pp. 3-19. http://dx.doi.org/10.1525/ california/9780520268685.003.0001.

ANISIMOVA, M., GIL, M., DUFAYARD, J.F., DESSIMOZ, C. and GASCUEL, O., 2011. Survey of branch support methods demonstrates accuracy, power, and robustness of fast likelihoodbased approximation schemes. Systematic Biology, vol. 60, no. 5, pp. 685-699. http://dx.doi.org/10.1093/sysbio/syr041. PMid:21540409.

ASHLEY, P., 2007. J. Fish welfare: current issues in aquaculture. Applied Animal Behaviour Science, vol. 104, no. 3-4, pp. 199-235. http://dx.doi.org/10.1016/j.applanim.2006.09.001.

BARROS, L.A., MORAES FILHO, J. and OLIVEIRA, R.L., 2007. Larvas de nematóides de importância zoonótica encontradas em traíras (Hoplias malabaricus Bloch, 1794) no município de Santo Antônio do Leverger, MT. Arquivo Brasileiro de Medicina Veterinária e Zootecnia, vol. 59, no. 2, pp. 533-535. http://dx.doi. org/10.1590/S0102-09352007000200042.

BERTOLLO, L.A.C., BORN, G.G., DERGAM, J.A., FENOCCHIO, A.S. and MOREIRA-FILHO, O., 2000. A biodiversity approch in the neotropical Erythrinidae fish, Hoplias malabaricus. Karyotypic survey, geographic distribution of cytotypes and cytotaxonomy considerations. Chromosome Research, vol. 8, no. 7, pp. 603-613. http://dx.doi.org/10.1023/A:1009233907558. PMid:11117356.

BIFI, A.G., 2013. Revisão taxonômica das espécies do grupo Hoplias malabaricus (Bloch, 1794) (Characiformes: Erythrinidae) da bacia do rio da Prata. Maringá: Universidade Estadual de Maringá, 51 p. Tese de Doutorado em Ecologia de Ambientes Aquáticos Continentais.

BLANCO, D.R., LUI, L.R., BERTOLLO, L.A.C., DINIZ, D. and MOREIRA FILHO, O., 2010. Characterization of invasive fish species in a river transposition region: evolutionary chromosome studies in the genus Hoplias (Characiformes, Erythrinidae). Reviews in Fish Biology and Fisheries, vol. 20, no. 1, pp. 1-8. http://dx.doi.org/10.1007/s11160-009-9116-3.
BOLDSYSTEMS, 2019 [viewed 29 November 2019]. The Barcoding of Life Data System [online]. Available from: www. barcodinglife.org

CLARE, E.L., LIM, B.K.M., ENGSTROM, D.J., EGER, L. and HEBERT, P.D.N., 2006. DNA barcoding of Neotropical bats: species identification and discovery within Guyana. Molecular Ecology Notes, no. 7, pp. 184-190.

CORANDER, J., SIREN, J. and ARJAS, E., 2008. Bayesian Spatial modeling of genetic Population Structure. Computational Statistics, vol. 23, no. 1, pp. 111-129. http://dx.doi.org/10.1007/ s00180-007-0072-x.

EXCOFFIER, L., LAVAL, G. and SCHNEIDER, S., 2007. Arlequin: a software for population data analysis. Version 3.1. Geneva: University of Geneva.

FU, Y. and LI, W.H., 1993. Statistical tests of neutrality of mutations. Genetics, vol. 133, no. 3, pp. 693-709. PMid:8454210.

GRASSI, D.J., SWARÇA, A.C., DERGAM, J.A., PASTORI, M.C. and FENOCCHIO, A.S., 2017. Cytogenetic characterization of Hoplias malabaricus (Bloch, 1794) from the Ctalamochita River (Córdoba, Argentina): first evidence for southernmost populations of this species complex and comments on its biogeography. Comparative Cytogenetics, vol. 11, no. 1, pp. 15-28. http:// dx.doi.org/10.3897/CompCytogen.v11i1.10262. PMid:28919946.

HALL, T.A., 1999. BioEdit: a user-friendly biological sequence alignment editor and analysis program for Windows 95/98/NT. Nucleic Acids Chemistry Ser A, vol. 41, pp. 95-98.

HEBERT, P.D.N., CYWINSKA, A., BALL, S.L. and DEWAARD, J.R., 2003. Biological identifications through DNA barcodes. Proceedings. Biological Sciences, vol. 270, no. 1512, pp. 313321. http://dx.doi.org/10.1098/rspb.2002.2218. PMid:12614582.

HUBERT, N. and RENNO, J.F., 2006. Historical biogeography of South American freshwater fishes. Journal of Biogeography, vol. 33, no. 8, pp. 1414-1436. http://dx.doi.org/10.1111/j.13652699.2006.01518.x.

JACOBINA, U.P., AFFONSO, P.R.A.M., CARNEIRO, P.L.S. and DERGAM, J.A., 2009. Biogeography and comparative cytogenetics between two populations of Hoplias malabaricus (Bloch, 1794) (Ostariophysi: Erythrinidae) from coastal basins in the State of Bahia, Brazil. Neotropical Ichthyology, vol. 7, no. 4, pp. 617-622. http://dx.doi.org/10.1590/S1679-62252009000400009.

JACOBINA, U.P., LIMA, S.M.Q., MAIA, D.G., SOUZA, G., BATALHA-FILHO, H. and TORRES, R.A., 2018. DNA barcode sheds light on systematics and evolution of neotropical freshwater trahiras. Genetica, vol. 146, no. 6, pp. 505-515. http://dx.doi. org/10.1007/s10709-018-0043-x. PMid:30361962.

JACOBINA, U.P., PAIVA, E. and DERGAM, J.A., 2011. Pleistocene karyotypic divergence in Hoplias malabaricus (Bloch, 1794) (Teleostei: Erythrinidae) populations in southeastern Brazil. Neotropical Ichthyology, vol. 9, no. 2, pp. 325-333. http://dx.doi. org/10.1590/S1679-62252011005000023.

KEANE, T.M., CREEVEY, C.J., PENTONY, M.M., NAUGHTON, T.J. and MCINERNEY, J.O., 2006. Assessment of methods for amino acid matrix selection and their use on empirical data shows that ad hoc assumptions for choice of matrix are not justified. BMC Evolutionary Biology, vol. 6, no. 1, pp. 29. http://dx.doi. org/10.1186/1471-2148-6-29. PMid:16563161.

KIMURA, M., 1980. A simple method for estimating evolutionary rate of base substitutions through comparative studies of nucleotide 
sequences. Journal of Molecular Evolution, vol. 16, no. 2, pp. 111-120. http://dx.doi.org/10.1007/BF01731581. PMid:7463489.

KUMAR, S., STECHER, G. and TAMURA, K., 2016. MEGA7: Molecular Evolutionary Genetics Analysis version 7.0. Molecular Biology and Evolution, vol. 33, no. 7, pp. 1870-1874. http://dx.doi. org/10.1093/molbev/msw054. PMid:27004904.

LIBRADO, P. and ROZAS, J., 2009. DnaSPv5: A software for comprehensive analysis of DNA polymorphism data. Bioinformatics, vol. 25, no. 11, pp. 1451-1452. http://dx.doi. org/10.1093/bioinformatics/btp187. PMid:19346325.

LÓPEZ-FERNÁNDEZ, H., ARBOUR, J.H., WINEMILLER, K.O. and HONEYCUTT, R.L., 2013. Testing for ancient adaptive radiations in Neotropical cichlid fishes. Evolution, vol. 67, no. 5, pp. v1321-v1337. http://dx.doi.org/10.1111/evo.12038. PMid:23617911.

LUNDBERG, J.G., MARSHALL, L.G., HORTON, B., MALABARBA, M.C.S.L. and WSSELINGH, F., 1998. The stage for Neotropical fish diversification: a history of tropical South American rivers. In: L.R. MALABARBA, R.E. REIS, R.P. VARI, Z.M.S. LUCENA and C.A.S. LUCENA, eds. Phylogeny and classification of neotropical fishes. Porto Alegre: EDIPUCRS, pp. 13-48.

MARQUES, D.F., SANTOS, F.A., SILVA, S.S., SAMPAIO, I. and RODRIGUES, L.R.R., 2013. Cytogenetic and DNA barcoding reveals high divergence within the trahira, Hoplias malabaricus (Characiformes: Erythrinidae) from the lower Amazon River. Neotropical Ichthyology, vol. 11, no. 2, pp. 459-466. http://dx.doi. org/10.1590/S1679-62252013000200015.

NORES, M., 2004. The implications of Tertiary and Quaternary sea level rise events for avian distribution patterns in the lowlands of northern South America. Global Ecology and Biogeography, vol. 13, no. 2, pp. 149-161. http://dx.doi.org/10.1111/j.1466882X.2004.00076.X.

OYAKAWA, O.T. and MATTOX, G.M.T., 2009. Revision of the Neotropical trahiras of the Hoplias lacerdae species-group (Ostariophysi: Characiformes: Erythrinidae) with descriptions of two new species. Neotropical Ichthyology, vol. 7, no. 2, pp. 117-140. http://dx.doi.org/10.1590/S1679-62252009000200001.

PAZZA, R. and JÚLIO JÚNIOR, H.F., 2003. Occurrence of three sympatric cytotypes of Hoplias malabaricus (Pisces, Erythrinidae) in Upper Paraná River foodplain (Brazil). Cytologia, vol. 68, no. 2, pp. 159-163. http://dx.doi.org/10.1508/cytologia.68.159.

PEREIRA, T.L., SANTOS, U., SCHAEFER, C.E., SOUZA, G.O., PAIVA, S.R., MALABARBA, L.R., SCHMIDT, E.E. and DERGAM, J.A., 2013. Dispersal and vicariance of Hoplias malabaricus (Bloch, 1794) (Teleostei, Erythrinidae) populations of the Brazilian continental margin. Journal of Biogeography, vol. 40, no. 5, pp. 905-914. http://dx.doi.org/10.1111/jbi.12044.

PERES, M.D., RENESTO, E., LAPENTA, A.S. and ZAWADZKI, C.H., 2002. Genetic Variability in Hoplias malabaricus (Osteichthyes: Erythrinidae) in Fluvial and Lacustrine Environments in the Upper Paraná River Floodplain (Parana State, Brazil). Biochemical Genetics, vol. 40, no. 7-8, pp. 209-223. http://dx.doi. org/10.1023/A:1019878716211. PMid:12296625.

PIRES, W.M.M., BARROS, M.C. and FRAGA, E.C., 2019. Diversidade genética em Hoplias malabaricus (BLOCH, 1794) revela diferentes linhagens em bacias maranhenses. In B.R. SILVA NETO, ed. Conceitos básicos da genética. Ponta Grossa: Atena. http://dx.doi.org/10.22533/at.ed.2141921068.
POSADA, D. and CRANDALL, K.A., 2001. A intraspecific gene genealogies: trees grafting into networks. Trends in Ecology \& Evolution, vol. 16, no. 1, pp. 37-45. http://dx.doi.org/10.1016/ S0169-5347(00)02026-7. PMid:11146143.

PRADO, C.P.A., GOMIERO, L.M. and FROEHLICH, O., 2006. Desova e cuidado parental em Hoplias malabaricus (Teleostei, Characiformes, Erythrinidae) no Pantanal Sul, Brasil. Brazilian Journal of Biology $=$ Revista Brasileira de Biologia, vol. 66, no. 2B, pp. 697-702. http://dx.doi.org/10.1590/S1519-69842006000400013. PMid:16906301.

RAMBAUT, A. and DRUMMOND, A.J., 2009 [viewed 29 November 2019]. Tracer v 1.5.0 [online]. Available from: http:// beast.bio.ed.ac.uk/Tracer.

RATNASINGHAM, S. and HEBERT, P.D.N., 2007. BOLD: the Barcode of Life Data System (www.barcodinglife.org). Molecular Ecology Notes, vol. 7, no. 3, pp. 355-364. http:// dx.doi.org/10.1111/j.1471-8286.2007.01678.x. PMid:18784790.

RONQUIST, F. and HUELSENBECK, J.P., 2003. MrBayes 3: bayesian phylogenetic inference under mixed models. Bioinformatics (Oxford, England), vol. 19, no. 12, pp. 1572-1574. http://dx.doi. org/10.1093/bioinformatics/btg180. PMid:12912839.

ROSA, R., VICARI, M.R., DIAS, A.L. and GIULIANO-CAETANO, L., 2014. New Insights into the Biogeographic and Karyotypic Evolution of Hoplias malabaricus. Zebrafish, vol. 11, no. 3, pp. 198-206. http://dx.doi.org/10.1089/zeb.2013.0953. PMid:24611575.

ROSSO, J.J., GONZÁLEZ-CASTRO, M., BOGAN, S., YAMILA, P., CARDOSO, Y.P., MABRAGAÑA, E., MATÍAS DELPIANI, M. and ASTARLOA, J.M.D., 2018. Integrative taxonomy reveals a new species of the Hoplias malabaricus species complex (Teleostei: erythrinidae). Ichthyological Exploration of Freshwaters, vol. 28 , no. 3, pp. 1-18.

ROSSO, J.J., MABRAGAÑA, E., GONZÁLEZ CASTRO, M. and DÍAZ DE ASTARLOA, J.M., 2012. DNA barcoding Neotropical fishes: recente advances from the Pampa Plain, Argentina. Molecular Ecology Resources, vol. 12, no. 6, pp. 999-1011. http://dx.doi. org/10.1111/1755-0998.12010. PMid:22984883.

SALZBURGER, W., EWING, G.B. and VON HAESELER, A., 2011. The performance of phylogenetic algorithms in estimating haplotype genealogies with migration. Molecular Ecology, vol. 20, no. 9, pp. 1952-1963. http://dx.doi.org/10.1111/j.1365294X.2011.05066.x. PMid:21457168.

SANGER, F., NICKLEN, S. and COULSON, A.R., 1977. DNA sequencing with chain-terminating inhibitors. Proceedings of the National Academy of Sciences of the United States of America, vol. 74, no. 12, pp. 5463-5467. http://dx.doi.org/10.1073/ pnas.74.12.5463. PMid:271968.

SANTOS, U., VÖLCKER, C.M., BELEI, F.A., CIOFFI, M.B., BERTOLLO, L.A.C., PAIVA, S.R. and DERGAM, J.A., 2009. Molecular and karyotypic phylogeography in the Neotropical Hoplias malabaricus (Erythrinidae) fish in eastern Brazil. Journal of Fish Biology, vol. 75, no. 9, pp. 2326-2343. http:// dx.doi.org/10.1111/j.1095-8649.2009.02489.x. PMid:20738690.

SITES JUNIOR, J.W. and MARSHALL, J.C., 2004. Operational criteria for delimiting species. Annual Review of Ecology Evolution and Systematics, vol. 35, no. 1, pp. 199-277. http://dx.doi. org/10.1146/annurev.ecolsys.35.112202.130128.

TAJIMA, F., 1989. Statistical method for testing the neutral mutation hypothesis by DNA polymorphism. Genetics, vol. 123, no. 3, pp. 585-595. PMid:2513255. 
TAKAHASHI, K., TERAI, Y., NISHIDA, M. and OKADA, N., 2001. Phylogenetic relationships and ancient incomplete lineage sorting among cichlid fishes in lake Tanganyika as revealed by analysis of the insertion of retroposons. Molecular Biology and Evolution, vol. 18, no. 11, pp. 2057-2066. http://dx.doi.org/10.1093/ oxfordjournals.molbev.a003747. PMid:11606702.

THOMPSON, J.D., HIGGINS, D.G. and GIBSON, T.J., 1994. CLUSTAL W: improving the sensitivity of progressive multiple sequence alignment through sequence weighting, positionsspecific gap penalties and weight matrix choice. Nucleic Acids Research, vol. 22, no. 22, pp. 4673-4680. http://dx.doi.org/10.1093/ nar/22.22.4673. PMid:7984417.

UTSUNOMIA, R., PANSONATO ALVES, J.C., PAIVA, L.R.S., COSTA SILVA, G.J., OLIVEIRA, C., BERTOLLO, L.A.C. and FORESTI, F., 2014. Genetic differentiation among distinct karyomorphs of the wolf fish Hoplias malabaricus species complex (Characiformes, Erythrinidae) and report of unusual hybridization with natural triploidy. Journal of Fish Biology, vol. 85, no. 5, pp. 1682-1692. http://dx.doi.org/10.1111/jfb.12526. PMid:25263542.

VICARI, M.R., ARTONI, R.F. and BERTOLLO, L.A.C., 2005. Comparative cytogenetics of Hoplias malabaricus (Pisces, Erythrinidae): a population analysis in adjacent hydrographics basins. Genetics and Molecular Biology, vol. 28, no. 1, pp. 103-110. http://dx.doi.org/10.1590/S1415-47572005000100018.

WARD, R.D., HANNER, R. and HEBERT, P.D.N., 2009. The campaign to DNA barcode all fishes, FISH-BOL. Journal of Fish Biology, vol. 74, no. 2, pp. 329-356. http://dx.doi.org/10.1111/j.10958649.2008.02080.x. PMid:20735564.

WARD, R.D., ZEMLAK, T.S., INNES, B.H., LAST, P.R. and HEBERT, P.D.N., 2005. DNA barcoding Australia's fish species. Philosophical Transactions of the Royal Society of London. Series B, Biological Sciences, vol. 360, no. 1462, pp. 1847-1857. http:// dx.doi.org/10.1098/rstb.2005.1716. PMid:16214743.

WEITZMAN, S.H., MENEZES, N.A. and WEITZMAN, M.J., 1998. Phylogenetic biogeography of the Glandulocaudini (Teleostei: Characiformes, Characidae) with comments on the distribution of other freshwater fishes in eastern and southeastern Brazil. In: P.E. VANZOLINI and W.R. HEYER, eds. Proceedings of Workshop on Neotropical Distribution Patterns. Rio de Janeiro: Academia Brasileira de Ciências, pp. 379-427.

WIENS, J.J. and PENKROT, T.L., 2002. Delimiting species based on DNA and morphological variation and discordant species limits in spiny lizards (Sceloporus). Systematic Biology, vol. 51, no. 1, pp. 6991. http://dx.doi.org/10.1080/106351502753475880. PMid:11943093. 


\section{Supplementary Material}

Supplementary material accompanies this paper.

Appendix S1. Haplotype tree for the COI gene obtained using the GTR $+\mathrm{I}+\mathrm{G}$ model, with a run of 4000000 generations. Support for the nodes was estimated by the test of approximate likelihood (Shimodaira-Hasegawa-like interpretation). This material is available as part of the online article from http://www.scielo.br/bjb 